\title{
Pollen germination and viability of castor bean (Ricinus communis L.): culture medium composition and environmental conditions
}

\section{Germinação e viabilidade de pólen de mamoneira (Ricinus communis L.): composição do meio de cultura e condições ambientais}

\author{
Cristina Copstein CUCHIARA ${ }^{1 ; 2}$; Patrícia Silva JUSTO ${ }^{3}$; Juliano Dutra SCHMITZ ${ }^{4}$; \\ Vera Lucia BOBROWSKI ${ }^{5}$
}

${ }^{1}$ Pesquisa financiada pela Coordenação de Aperfeiçoamento de Pessoal de Nível Superior - CAPES e pela Financiadora
de Estudos e Projetos - FINEP/RS;
2 Autor para correspondência (Correspondig author); Doutor; Universidade Federal de Pelotas; Laboratório de
Cultura de Tecidos de Plantas, Instituto de Biologia, Departamento de Botânica, Campus Universitário S/N., CP
354, CEP 96010-900, Capão do Leão, RS, Brasil; cccuchiara@ @hotmail.com
${ }^{3}$ Mestre; Universidade Federal de Pelotas; patsjusto@hotmail.com
${ }^{4}$ Mestre, Universidade Federal de Pelotas; jdsagro@gmail.com
${ }^{5}$ Doutor, Universidade Federal de Pelotas; vera.bobrowski@gmail.com

Recebido em: 26-07-2014; Aceito em: 09-12-2014

\begin{abstract}
The aim of the study was to select the basic components of culture medium and environmental conditions for in vitro pollen germination and viability of castor bean (Ricinus communis L.) of the cultivars IAC 80, AL Guarany 2002 and the hybrid Lara. The four experiments were performed using basic culture medium, where different $\mathrm{pH}$ values $(5,6,7$ and 8$)$, incubation temperatures $(15,20,25$ and $30 \stackrel{\circ}{\circ})$, sucrose concentrations $(0 ; 5 ; 10$ and $20 \%)$ and combinations of boron $\left(4,8\right.$ and $\left.10 \mathrm{mg} \mathrm{L}^{-1}\right)$ with sucrose $(0 ; 5 ; 10$ and $20 \%)$ were evaluated. The culture medium was placed in excavated plates and the pollen was distributed on the medium surface. The plates were incubated for one hour. The experimental design was completely randomized and there were 100 pollen grains analyzed in each of the six replications of every treatment. The $\mathrm{pH}$ value above 6.0 reduced the amount of pollen grains germinated. Also, temperature of $20^{\circ} \mathrm{C}$ and different concentrations of sucrose can be used in germination and pollen tube growth in the castor bean. For all genotypes, the best results concerning the use of boric acid was the $4 \mathrm{mg} \mathrm{L}^{-1}$ combined with 10,5 , and $10 \%$ sucrose for the 'IAC 80 ', 'AL Guarany 2002' and 'Lara', respectively.
\end{abstract}

Additional keywords: boron; $\mathrm{pH}$; pollen viability; sucrose; temperature.

\section{Resumo}

O presente trabalho teve como objetivo selecionar os componentes básicos do meio de cultura e as condições ambientais para germinação in vitro e viabilidade polínica de grãos de pólen de mamoneira (Ricinus communis L.) das cultivares IAC 80 e AL Guarany 2002 e do híbrido Lara. Foram conduzidos quatro ensaios utilizando meio de cultura básico, onde foram avaliados: diferentes valores de $\mathrm{pH}(5$, 6,7 e 8), diferentes temperaturas de incubação $\left(15,20,25\right.$ e $\left.30^{\circ} \mathrm{C}\right)$, diferentes concentrações de sacarose $(0 ; 5 ; 10$ e $20 \%)$ e combinações de boro $\left(4,8\right.$ e $\left.10 \mathrm{mg} \mathrm{L}^{-1}\right)$ com sacarose $(0 ; 5 ; 10$ e $20 \%)$. 0 meio de cultura foi vertido em placas de lâmina escavada e o pólen distribuído sobre a superfície do meio. As placas foram incubadas por uma hora. $O$ delineamento experimental foi inteiramente casualizado e foram analisados 100 grãos de pólen em cada uma das seis repetições de cada tratamento. $\mathrm{O}$ valor de $\mathrm{pH}$ acima de 6,0 diminui a quantidade de grãos de pólen germinados. A temperatura de $20^{\circ} \mathrm{C}$ e as diferentes concentrações de sacarose podem ser empregadas na germinação e no crescimento do tubo polínico de mamona. Para todos os genótipos, os melhores resultados em relação ao uso de ácido bórico foi de $4 \mathrm{mg} \mathrm{L}^{-1}$ combinados com 10, 5 e 10\% de sacarose para 'IAC 80', 'AL Guarany 2002' e 'Lara', respectivamente.

Palavras-chave adicionais: boro; $\mathrm{pH}$; sacarose; temperatura; viabilidade polínica.

\section{Introduction}

Among biodiesel production raw materials is castor bean (Ricinus communis L.), which belong to the Euphorbiaceae family, which includes different types of plants native to the tropical region (WEISS, 1983). The castor oil plant has considerable economic potential, since its seeds give rise to castor beans cake and oil after industrialized which, among several utilities, is used in plastics, steel, soap manufacture, perfumes, tanning, paint and varnishes industries (ZUCHI et al., 2010). Due to its great adaptability to the Brazilian semi-arid region, castor bean 
production is concentrated in the Northeast region (146.500 hectares) (IBGE, 2012). The culture is traditionally produced in small and medium properties in this region, having an important social value as income and jobs generator in the field (VITORINO et al., 2012).

Castor oil plant breeding programs in Brazil have as its main objective the development of adapted and productive cultivars in major producing regions and farming systems. Low stature, uniform fruit ripening, precocity and productivity are among bioagronomic characters most targeted by breeders. Castor oil plant production in the Northeast is basically made in small family character properties with rustic cultivars use. However, in large scale production systems, with high standard of technology used, hybrids with high production potential are typically used. In this case, these hybrids are more suitable because they have better production response to high doses of agricultural inputs and agronomic techniques employed, with mechanical harvesting possibility among them (SAVY FILHO, 2005).

Because of the importance of employing commercial hybrids for the production of castor bean success on a large scale, the use of progenitors that transmit a high percentage of female flowers, combined with the characters previously mentioned, are desirable features to compose new genotypes (SAVY FILHO, 2005). Based on the above, pollen grains viability and development by in vitro germination knowledge are central to the fertilization technique in plants (NIESTCHE et al, 2009; ACAR \& KAKANI, 2010; CHAGAS et al., 2010).

In in vitro germination tests, pollen is spread over a culture medium and viability is observed by microscope, through the percentage of pollen grains that emit pollen tube (VEIGA et al., 2012). However, this method is influenced by different factors, with emphasis on constituents of the culture medium, $\mathrm{pH}$, temperature and incubation time (STANLEY \& LINSKENS, 1974; FRANZON \& RASEIRA, 2006). In addition, several studies have been conducted to establish and standardize culture medium and appropriate conditions to assess pollen viability, stressing the importance of works on assessing factors influence in pollen grains of several species longevity, especially in castor oil plant (SALLES et al., 2006; CHAGAS et al., 2010).

Therefore, in order to increase species reproductive biology knowledge, this study aimed to select culture medium basic components and environmental conditions for in vitro germination and pollen viability of IAC 80, AL Guarany 2002 and hybrid Lara cultivars pollen grains.

\section{Material and methods}

For this study development, inflores- cences from two castor oil plant cultivars were collected: IAC 80, AL Guarany 2002 and the hybrid Lara, from Embrapa Temperate Climate CPACT experimental field, located in the city of Pelotas, latitude $31^{\circ} 41^{\prime} \mathrm{S}$ and longitude $52^{\circ} 21^{\prime} \mathrm{W}$. Samples were collected between 8 am and 9 am, once pollen release occurs from sunrise until noon, depending on the temperature, and usually is completed in four to five hours (VEIGA et al., 2012; FREITAS, 2013). The inflorescences were taken after collection immediately to the laboratory and maintained in distilled water at room temperature until flower opening and subsequent grains removal for analysis.

Four tests were conducted in sequence, as the results obtained in each one were used in subsequent tests.

\section{Test with different $\mathrm{pH}$ in the culture medium}

The experiment was conducted using a culture medium containing $0.8 \mathrm{~g}$ agar and $10 \mathrm{~g}$ sucrose in $100 \mathrm{ml}$ of distilled water, according to GOMES et al. (2003). The medium employed had its $\mathrm{pH}$ adjusted to 5, 6, 7 and 8. After, it was heated to complete agar dissolution and deposited in Kline excavated slides containing twelve cavities. Pollen from each genotype was inoculated on the medium surface with a brush so as to promote material uniform distribution. Slides were placed inside petri dishes containing humid germitest paper, simulating a humid chamber, and transferred to a BOD incubator at $20^{\circ} \mathrm{C}$ for one hour.

\section{Test with different incubation temperatures}

This test was conducted according to the previous procedure, using the culture medium mentioned above with the $\mathrm{pH}$ adjusted to 6.0. Petri dishes were then transferred to BOD incubators at different temperatures $(15,20,25$ and $30^{\circ} \mathrm{C}$ ) for one hour.

\section{Test with different sucrose concentrations}

In this test, a culture medium with $\mathrm{pH}$ 6.0 , supplemented with different sucrose concentrations of $0,5,10$ and $20 \%$, was used. After pollen inoculation, plates were incubated at $20^{\circ} \mathrm{C}$ temperature. Medium preparation and pollen inoculation procedure was the same mentioned in the first item.

\section{Test with different boron and sucrose concentrations}

In the fourth test, 4,8 and $10 \mathrm{mgL}^{-1}$ boric acid concentrations combined with different sucrose concentrations $(0,5,10$ and $20 \%)$, with medium $\mathrm{pH}$ adjusted to 6.0 were tested. After pollen inoculation, plates were incubated at $20{ }^{\circ} \mathrm{C}$ temperature. Medium preparation and pollen inoculation procedure was the same mentioned in the first item. 
For all tests the statistical design was completely randomized in a $3 \times 4$ factorial arrangement ( 3 genotypes $\times 4$ treatments). Each Kline plate cavity was considered a repetition and four repetitions per treatment were evaluated, with repetitions being formed of 100 scores of pollen grains, germinated or not, with the help of an optical microscope with a 10x objective. Pollen grains with pollen tube length equal to or greater than its own pollen diameter were considered germinated (PASQUAL et al., 1982).

\section{Statistical analysis}

The results were submitted to variance analysis and means were compared using Duncan test $(\alpha=1 \%)$, with the assistance of SANEST statistical program (ZONTA \& MACHADO, 1984). Data, expressed in percentages, were transformed following the arc sine of $(X / 100)^{1 / 2}$, where $X$ represents the percentage obtained for each variable. In order to deploy factor interaction effects, polynomial regression analysis was performed, being represented as individual charts for each test.

\section{Results and discussions}

According to the analysis of variance (Table 1) related to the effects of different $\mathrm{pH}$, temperature and sucrose levels, there was highly significant differences in the interaction of the studied factors $(p<0.01)$.

Table 1 - Analysis of variance (ANOVA) for the variable germinated castor oil plant pollen grains genotypes under different $\mathrm{pH}$, temperature, and sucrose levels.

\begin{tabular}{|c|c|c|c|c|}
\hline \multirow[t]{2}{*}{ Variation Causes } & \multirow[t]{2}{*}{$\mathrm{GL}$} & \multicolumn{3}{|c|}{$\begin{array}{c}\text { Mean Square } \\
\text { Germination (\%) }\end{array}$} \\
\hline & & $\mathrm{pH}$ & Temperature & Sucrose \\
\hline Genotypes & 2 & $788.824^{* *}$ & $1944.450^{* *}$ & $84.481^{*}$ \\
\hline Levels & 3 & $1313.984^{* *}$ & $1949.207^{\star *}$ & $2590.149^{* *}$ \\
\hline Genotypes x levels & 6 & $324.757^{* *}$ & $551.944^{* *}$ & $1252.088^{* *}$ \\
\hline Residues & 36 & 48.321 & 18.818 & 25.507 \\
\hline C.V. (\%) & & 14.326 & 11.336 & 14.698 \\
\hline General Mean & & 48.521 & 32.266 & 34.362 \\
\hline
\end{tabular}

The culture medium, to be considered good, should provide at least $50 \%$ of germinated grains with well-developed tubes. As aging occurs in pollen grains, the germination percentage and pollen tubes length decrease. Even if the pollen seems weak, some vigorous pollen tubes presence suggests that at least moderately effective fertilization will occur, despite the low germination percentage (SCORZA \& SHERMAN, 1995; FREITAS, 2013).

The $\mathrm{pH}$ is a major factor in the culture medium and influences nutrients availability, phytoregulators and agar solidification degree (PASQUAL et al., 2002). In relation to $\mathrm{pH}$, it was observed that for IAC 80 and AL Guarany 2002 cvs., there is a linear pollen germination reduction as the $\mathrm{pH}$ increases, with higher germination percentage (about $80 \%$ ) to $\mathrm{pH} 5$ and, however, with germination inhibition at higher values. Nevertheless, for Lara hybrid there was no statistically significant difference in germinated pollen grains percentage (about $50 \%$ ) at different $\mathrm{pH}$ tested (Figure $1 \mathrm{~A}$ ).

From the results obtained, it was found that the $\mathrm{pH}$ level stimulated cultivars pollen germination process, confirming STANLEY \& LINSKENS (1974) observations, who demonstrated that the culture medium $\mathrm{pH}$ influences pollen germination induction process.

The temperature is another factor with significant influence on pollen germination, with thermal stress being the main productivity and culture adaptability limiter, especially if extreme temperatures coincide with the critical stages of plant development (STEVENS \& RUDICH, 1978; MARTINS, 2014). According to HEDHLY (2011), temperature may affect: 1) gamete formation, which may reduce gametes quality, which results in problems during fertilization and, in severe cases, may lead to its complete sterility; 2) the progamic stage, from pollination to fertilization, both in the male part as in the female, with problems in pollen grain germination, pollen tube growth, stigma receptivity, viability and egg cell longevity 3) embryo formation. As for the pollen germination percentage, in this study there was an oscillation between different temperatures tested, with higher values between 20 and $25^{\circ} \mathrm{C}$ temperatures, being possible to establish $20{ }^{\circ} \mathrm{C}$ temperature as the ideal (Figure 1B). 

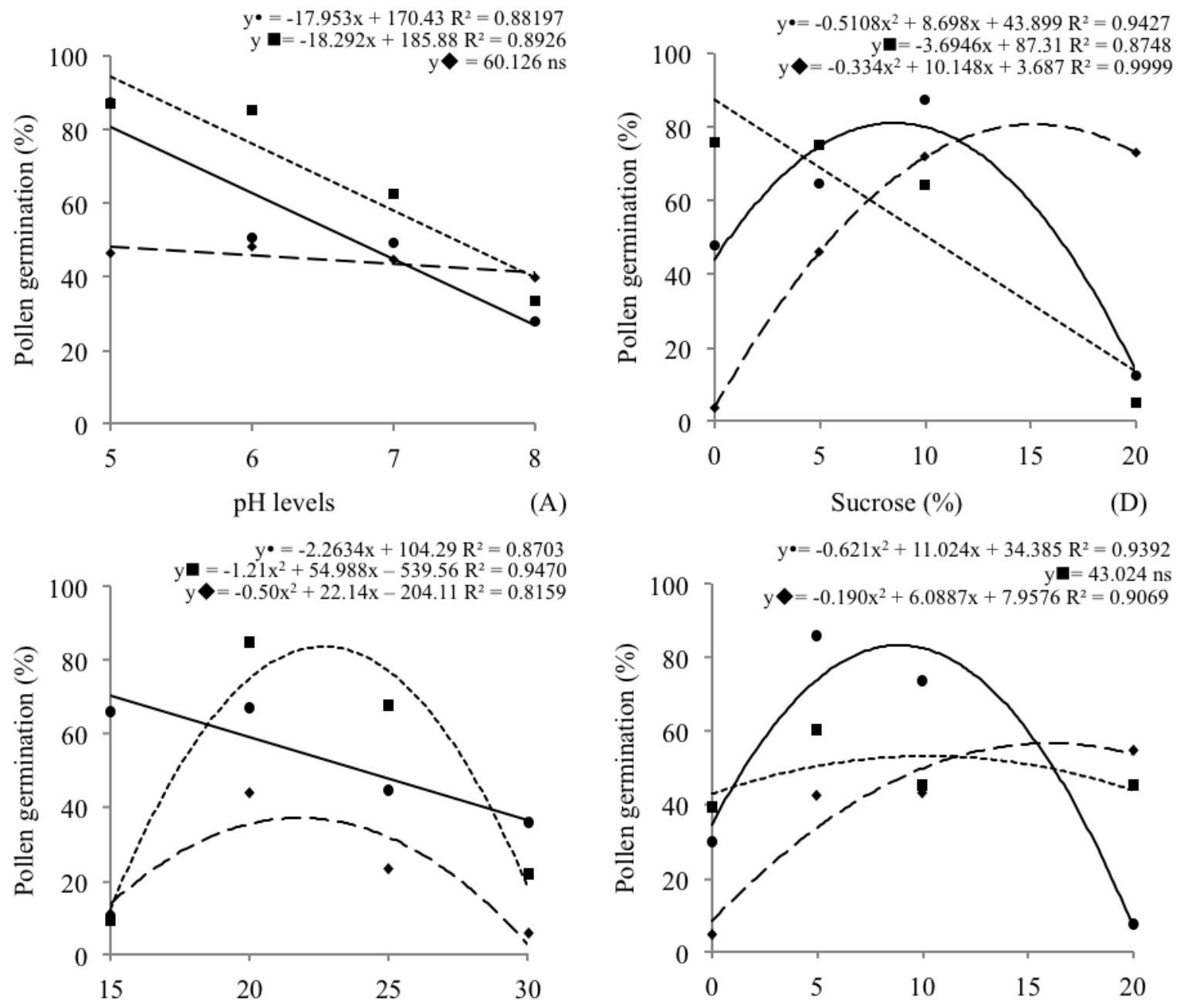

Temperature $\left({ }^{\circ} \mathrm{C}\right)$

(B)
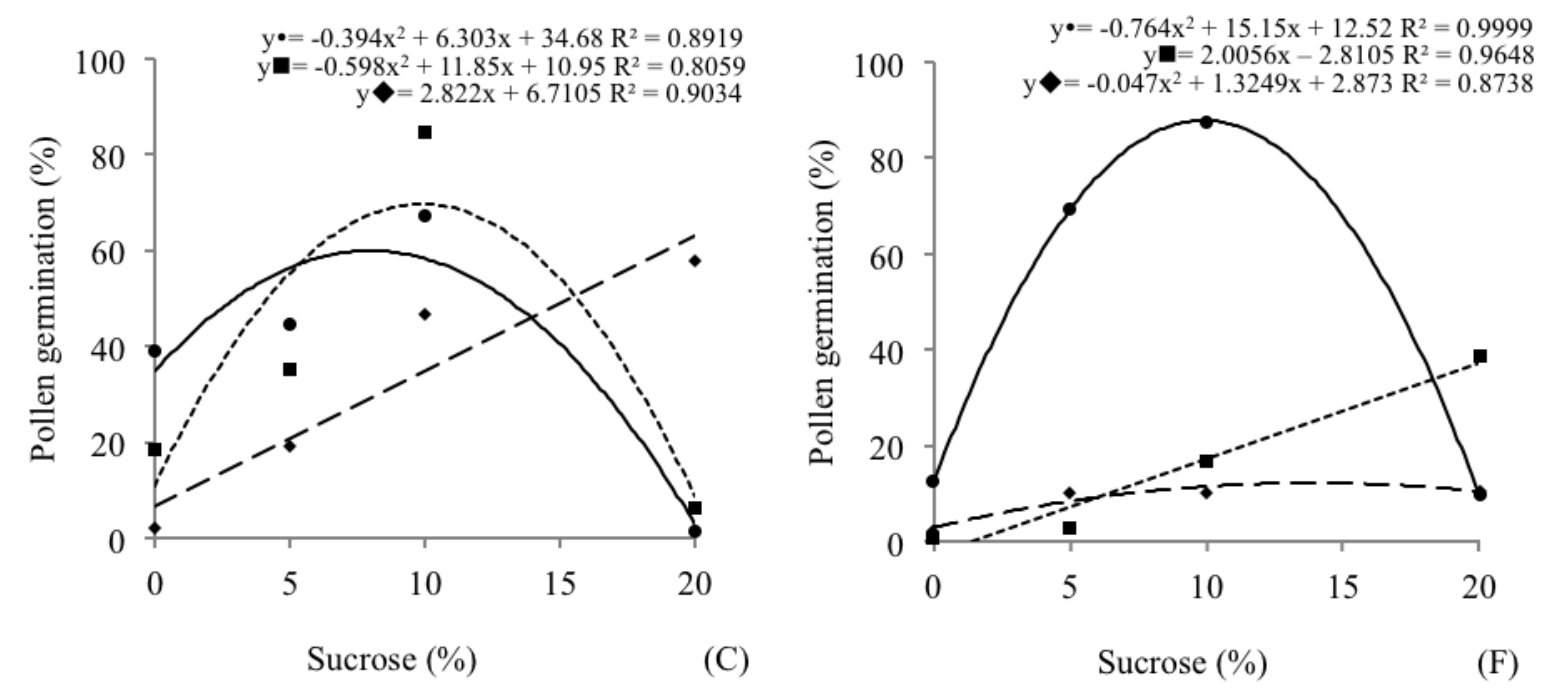

Figure 1 - Percentage of germinated pollen grains of cultivars IAC $80(\bullet)$, AL Guarany $2002(\boldsymbol{\bullet})$ cultivars, and the hybrid Lara $(\bullet)$ submitted to $\mathrm{pH}$ levels $(\mathrm{A})$, temperature $(\mathrm{B})$, sucrose $(\mathrm{C})$, and combinations of $4(\mathrm{D}), 8(\mathrm{E})$ and $10(\mathrm{~F}) \mathrm{mg} \mathrm{L}^{-1}$ of boron with sucrose. ns - not significant at $1 \%$ probability by Duncan test.

However, the ideal pollen germination temperature range varies among species. In the case of peach tree pollen grains, pollen tube emission occurs at $24^{\circ} \mathrm{C}$ (CHAGAS et al., 2009), while apple tree pollen (NUNES et al., 2001) and sweet oranges varieties (RAMOS et al., 2008) 
occurs around $25^{\circ} \mathrm{C}$, and pear tree (Pyrus spp.) varieties pollen grains germination occurs at $28^{\circ} \mathrm{C}$ (CHAGAS et al., 2010). In addition, higher incubation temperatures, i.e., between 25 and $30^{\circ} \mathrm{C}$ may be used for Eugenia involucrate pollen germination (FRANZON \& RASEIRA, 2006). In pepper varieties (Capsicum spp.), temperatures above $40{ }^{\circ} \mathrm{C}$ are limiting for the germination of the species (FRANZON \& RASEIRA, 2006).

For cvs.AL Guarany 2002 and Lara, the temperature of $15{ }^{\circ} \mathrm{C}$ provided less than $20 \%$ of germinated pollen grains, but for cV. IAC $80,70 \%$ of pollen tube emission was observed, with a linear decreasing trend according to increasing incubation temperature. The responses observed for this cultivar are indicative of cold tolerance, being an important result for its cultivation in subtropical regions.

With respect to sucrose, its addition as a source of carbohydrates aims to meet the metabolic needs of explants, participating in energy generation or as a source of carbon skeletons for biosynthetic processes involved in cell differentiation (MARTINS, 2014). The highest germination percentage by increasing sucrose concentration may be explained by the greater energy availability in carbohydrate form, destined for the pollen tube development and growth (CHAGAS et al.,
2010). Different sugar types in varying concentrations have been a major component of the culture medium, which permits pollen tube emission (SALLES et al., 2006).

As shown in Figure $1 \mathrm{C}$ about sucrose concentration, CVs. IAC 80 and AL Guarany 2002 pollen grains showed a similar behavior, with the best result obtained at 10\% concentration, from which and in the absence of it a decrease in the percentage of pollen grains germinated happened. For the hybrid Lara there was a linear increase in the percentage of germinated pollen grains by increasing the sucrose concentration of the medium, with an optimal concentration of $20 \%$.

According to the analysis of variance from Table 2, the test with 4,8 and $10 \mathrm{mgL}^{-1}$ of boric acid and different sucrose concentrations showed highly significant differences for factor interaction $(p<0.01)$. The addition of boron is important for pollen germination and its responses vary according to species, whose action mechanism is to interact with the sugar and form an ionizable sugar-borate complex, which reacts faster with cell membranes (PFAHLER 1967). RAMOS et al. (2008) found that the addition of boron to the medium increased germination percentage and pollen tube length of several species.

Table 2 - Analysis of variance (ANOVA) for the variable germinated castor oil plant pollen grains genotypes under different sucrose and boric acid combinations.

\begin{tabular}{lcccc}
\hline & & \multicolumn{3}{c}{$\begin{array}{c}\text { Mean Square } \\
\text { Germination }(\%)\end{array}$} \\
\cline { 3 - 5 } & $\mathrm{GL}$ & $\begin{array}{c}4 \mathrm{mg} \mathrm{L}^{-1} \\
\text { boric acid }\end{array}$ & $\begin{array}{c}8 \mathrm{mg} \mathrm{L}^{-1} \\
\text { boric acid }\end{array}$ & $\begin{array}{c}10 \mathrm{mg} \mathrm{L}^{-1} \\
\text { boric acid }\end{array}$ \\
\hline Genotypes & 2 & $90.451^{*}$ & $370.703^{* *}$ & $2978.251^{* *}$ \\
Sucrose & 3 & $2097.545^{* *}$ & $1556.253^{* *}$ & $1403.183^{* *}$ \\
Genotype x Sucrose & 6 & $1797.972^{* *}$ & $902.175^{* *}$ & $1124.259^{* *}$ \\
Residues & 36 & 29.526 & 28.296 & 13.659 \\
\hline C.V. $(\%)$ & & 11.992 & 12.961 & 14.493 \\
\hline General Mean & & 45.312 & 41.041 & 25.502 \\
\hline
\end{tabular}

${ }^{*}$ and ${ }^{* \star}$ related to 5 and $1 \%$ probability levels, respectively.

The need of boron addition in the culture medium for pollen grains germination depends, among other factors, on the species and variety (RAMOS et al., 2008). According to Figure 1D, Cv. IAC 80 and the hybrid Lara, subjected to $4 \mathrm{mg}$ $\mathrm{mgL}^{-1}$ of boric acid and different sucrose levels, presented a similar behavior, in which germinated pollen percentage increased with sucrose concentration growth, with the best result obtained in $10 \%$ sucrose. For cv. IAC $80,20 \%$ concentration was toxic, making a drastic reduction in in vitro germination. For the hybrid Lara, sucrose absence inhibited pollen tube emission, although in 10 and $20 \%$ concentrations an increase in the amount of pollen grains germinated was observed (around 70\%). Unlike other culti- vars, 'AL Guarany 2002' showed a linear decrease in germination according to the increase of sucrose concentration, with the best results obtained in the absence of sucrose or in 5\% concentration. A sharp decrease in germination occurred above these values.

Regarding the use of $8 \mathrm{mg} \mathrm{L}^{-1}$ boron for CV. IAC 80 , in the combination of more than $5 \%$ sucrose concentrations, a gradual reduction in germination happened (Figure 1E). However, the use of $5 \%$ sucrose gave $85 \%$ of this cultivar pollen germination. About CV. AL Guarany 2002, all sucrose concentrations combined with $8 \mathrm{mg} \mathrm{L}^{-1}$ boric acid were satisfactory for the pollen tube development. However, $5 \%$ concentration, as well as in "IAC 80", caused $60 \%$ of germination (Figure 
1E). For the hybrid Lara, it was observed that increasing the carbohydrate amount increases the amount of pollen grains germinated, with the best treatment being the one with $20 \%$ sucrose, in which $54 \%$ of the pollen grains emanated pollen tube, similar results to the ones observed in a $4 \mathrm{mg} \mathrm{L}^{-1}$ boron concentration. These data corroborate those obtained in the rootstock of $\mathrm{M} 9$ apple tree pollen grains, which showed gradual increase in germination up to $20 \%$ sucrose concentration (DANTAS et al., 2005).

The medium with $10 \mathrm{mg} \mathrm{L}^{-1}$ boron without sucrose inhibited castor oil plant pollen grains germination in the three genotypes analyzed, where an average of only $10 \%$ of pollens emanated pollen tubes (Figure 1F). For cV. IAC 80 , germination was of $69 \%$ when $5 \%$ sucrose was used. On the other hand, it increased to $87 \%$ when $10 \%$ sucrose was used and showed a drastic reduction to $9 \%$ in in vitro germination, when $20 \%$ sucrose was used. For pollen from cv. $\mathrm{AL}$ Guarany 2002 and hybrid Lara, $10 \mathrm{mgL}^{-1}$ boron concentration had a more pronounced inhibitory effect than for cV. IAC 80. In cV. AL Guarany 2002, there was a linear increase with increasing sucrose concentration, reaching $38 \%$ germination when using $20 \%$ sucrose. For hybrid Lara, inhibitory results were striking where all sucrose concentrations showed an average of $10 \%$ pollen tubes emission.

Data obtained from the combination of sucrose and concentrations of 4 and $8 \mathrm{mg} \mathrm{L}^{-1}$ boric acid confirm the results obtained in the third test of this study, where only sucrose concentrations without boron addition were used. However, it was observed that boron increases pollen tubes emission number. According to ALMEIDA et al. (1987), boric acid addition, generally, increases sucrose efficiency in pollen germination and pollen tube growth. In this study, this was not observed, because the $10 \mathrm{mgL}^{-1}$ boron concentration did not favored pollen tube emission or growth.

\section{Conclusions}

The medium $\mathrm{pH}$ value above 6.0 decreases the amount of germinated pollen grains for cultivars of castor oil plants IAC 80 and AL Guarany 2002.

The temperature of $20^{\circ} \mathrm{C}$ is the most suitable for the germination and growth in the pollen tube. Sucrose used in 5 and 10\% concentrations may be employed in in vitro germination of cultivars IAC 80 and AL Guarany 2002. However, for the hybrid Lara $20 \%$ concentration shows better results.

For all genotypes, the best result regarding boric acid use was of $4 \mathrm{mg} \mathrm{L}^{-1} \mathrm{com}$ bined with 10, 5 and 10\% sucrose for 'IAC 80', 'AL Guarany 2002' and 'Lara', respectively.

\section{Acknowledgements}

The authors thank to Coordenação de Aperfeiçoamento de Pessoal de Nível Superior (CAPES), to Financiadora de Estudos e Projetos (FINEP/RS) and to Embrapa Clima Temperado (CPACT) for the granting of scholarships, providing samples and for the support of the analysis.

\section{References}

ACAR, I.; KAKANI, V. G. The effects of temperature on in vitro pollen germination and pollen tube growth of Pistacia spp. Scientia Horticulturae, Amsterdam, v.125, p.569-572, 2010.

ALMEIDA, F. C. G.; SILVA, J. F.; ALVES, J. F.; SILVA, F. P.; ALMEIDA, F. A. G. Estudo da germinação do pólen do algodão, Gossypium hirsutum L. in vitro. II - efeitos do ácido bórico e do sulfato de manganês. Revista Ciência Agronômica, Fortaleza, v.18, n.1, p.117-123, 1987.

CHAGAS, E. A.; BARBOSA, W.; PIO, R.; DALL'ORTO, F. A. C.; TIZATO, L. H. G.; SAITO, A.; CHAGAS, P. C.; SCARPARE FILHO, J. A. Germinação in vitro de grãos de pólen de Prunuspersica (L.) BATSCH vulgaris. Bioscence Journal, Uberlândia, v.25, n.5, p.8-14, 2009.

CHAGAS, E. A.; PIO, R.; CHAGAS, P. C.; PASQUAL, M.; BETTIOL NETO, J. E. Composição do meio de cultura e condições ambientais para germinação de grãos de pólen de porta-enxertos de pereira. Ciência Rural, Santa Maria, v.40, n.2, p.261-266, 2010.

DANTAS, A. C. M.; PEIXOTO, M. L.; NODARI, R. O.; GUERRA, M. P. Viabilidade do pólen e desenvolvimento do tubo polínico em macieira (Malus spp.). Revista Brasileira de Fruticultura, Jaboticabal, v.27, n.3, p.356-359, 2005.

FRANZON, R. C.; RASEIRA, M. C. B. Germinação in vitro e armazenamento do pólen de Eugenia involucrata DC (Myrtaceae). Revista Brasileira de Fruticultura, Jaboticabal, v.28, n.1, p.18-20, 2006.

FREITAS, L. L. Efeito da temperatura sobre a germinação in vitro de grãos de pólen de dois genótipos de mamoeiro (Carica papaya L.). 2013. 58f. Dissertação (Mestrado em Genética e Melhoramento de Plantas) - Centro de Ciências e Tecnologias Agropecuárias, Universidade Estadual do Norte Fluminense Darcy Ribeiro, Campos de Goytacazes, 2013.

GOMES, P. R.; RASEIRA, M. C. B.; BAUDET, L. L.; PESKE, S. T. Armazenamento do grão de pólen de cebola (Allium cepa L.). Revista Brasileira de Sementes, Londrina, v.25, n.1, p.14-17, 2003. 
HEDHLY, A. Sensitivity of flowering plant gametophytes to temperature fluctuations. Environmental and Experimental Botany, Elmsford, v.74, p.9-16, 2011.

IBGE. Instituto Brasileiro de Geografia e Estatística. Estatisticas: Lavouras Permanentes. Disponível em: < http://www.ibge.gov.br/estadosat/>. Acesso em: 26 jul. 2014.

MARTINS, K. C. Cruzabilidade, constituição genômica e viabilidade polínica em Capsicum spp. 2014. 122f. Tese (Tese em Genética e Melhoramento de Plantas) - Centro de Ciências e Tecnologias Agropecuárias, Universidade Estadual do Norte Fluminense Darcy Ribeiro, Campos de Goytacazes, 2014.

NIETSCHE, S.; PEREIRA, M. C. T.; OLIVEIRA, C.; DIAS, M. M.; REIS, S. T. Viabilidade dos grãos de pólen de flores de pinheira (Annona squamosa) em diferentes horários. Ciência e Agrotecnologia, Lavras, v.33, n.2, p.527-531, 2009.

NUNES, J. C. O.; DANTAS, A. C. M.; PEDROTTI, E. L.; ORTH, A. I.; GUERRA, M. P. Germinação de pólen in vitro e receptividade do estigma em macieira cvs. Fuji e Golden Delicious. Revista Brasileira de Fruticultura, Jaboticabal, v.23, n.1, p.35-39, 2001.

PASQUAL, M.; PETRI, J. L.; MATTOS, C. S. Polinização da macieira III: cultivares BR-1 e Mollies Delicious. Pesquisa Agropecuária Brasileira, Brasília, v.17, n.10, p.1477-1481, 1982.

PASQUAL, M.; FINOTTI, D. R.; DUTRA, L. F.; CHAGAS, E. A.; RIBEIRO, L. O.Cultivo in vitro de embriões imaturos de tangerineira 'Poncã' em função do $\mathrm{pH}$ e ágar. Revista Brasileira de Agrociência, Pelotas, v.8, n.3, p.199-202, 2002.

PFAHLER, P. L. In vitro germination and pollen tube growth of maize (Zea mays L.) pollen: calcium and boron effects. Canadian Journal of Botany, Toronto, v.45, p.839-845, 1967.

RAMOS, J. D.; PASQUAL, M.; APARECIDA SALLES, L.; CHAGAS, E. A.; PIO, R. Receptividade do estigma e ajuste de protocolo para germinacão in vitro de grãos de pólen de citros. INCI, Caracas, v.33, n.1, p.51-55, 2008.
SALLES, L. A.; RAMOS, J. D.; PASQUAL, M.; JUNQUEIRA, K. P.; SILVA, A. B. Sacarose e pH na germinação in vitro de grãos de pólen de citros. Ciência e Agrotecnologia, Lavras, v.30, n.1, p.170-174, 2006.

SAVY FILHO, A. Mamona: tecnologia agrícola. Campinas: EMOPI, 2005. 105p.

SCORZA, R.; SHERMAN, W. B. Peaches. In: JANIK, J., MOORE, J. N. (Ed.). Fruit breeding. New York: John Willey \& Sons, 1995. p.325-440.

STANLEY, R. G.; LINSKENS, H. F. Pollen biology, biochemistry and management. New York: Springer-Verlag, 1974. 172p.

STEVENS, M. A.; RUDICH, J. Genetic potencial for overcoming physiological limitations on adaptability, yield, and quality in the tomato. HortScience, Alexandria, v.13, p.673-78, 1978.

VITORINO, H. S.; MARTINS, D.; COSTA, S. Í. A.; MARQUES, R. P.; SOUZA, G. S. F.; CAMPOS, C. $F$. Eficiência de herbicidas no controle de plantas daninhas latifoliadas em mamona. Arquivos do Instituto Biológico, São Paulo, v.79, n.1, p.127$-131,2012$.

VEIGA, P. O. A.; VON PINHO, R. G. V.; VON PINHO, E. V. R.; VEIGA A. D.; OLIVEIRA, K. C.; DINIZ, R. P. Meios de cultura para germinação de grãos de pólen de milho. Revista Agrarian, Dourados, v.5, n.17, p.206-211, 2012.

WEISS, E. A. Castor. In: WEISS, E. A. Oilseed crops. London: Longman, 1983. p.31-99.

ZONTA, E. P.; MACHADO, A. A. SANEST - Sistema de Análise Estatística para Microcomputadores. Registrado na Secretaria Especial de Informática sob no 066060 - categoria A. Pelotas: Universidade Federal de Pelotas, 1984.

ZUCHI, J.; ZANUNCIO, J. C.; BEVILAQUA, G. A. P.; PESKE, S. T.; SILVA, S. D. A. Componentes do rendimento de mamona segundo a ordem floral e época de semeadura no Rio Grande do Sul. Revista Ciência Agronômica, Fortaleza, v.41, n.3, p.380-386, 2010. 